\title{
Takayasu arteritis in pregnancy: A case series
}

\section{Ipsita Mohapatra ${ }^{1}$, Subha Ranjan Samantaray ${ }^{1}$, G Priyanka ${ }^{2}$, Achanta Vivekananda ${ }^{1}$,}

1 Professor, Obstetrics and Gynecology, Prathima Institute of Medical Sciences, Karimnagar, Telangana.

2 Post Graduate Student, Obstetrics and Gynecology, Prathima Institute of Medical Sciences, Karimnagar, Telangana.

Address for correspondence: Dr. Subha Ranjan Samantaray, Professor, Department of Obstetrics and Gynecology, Prathima Institute of Medical Sciences, Karimnagar, Telangana, India.

Email: drshubha2009@gmail.com

DOI : 10.47799/pimr.0802.23

\section{Abstract}

Takayasu arteritis is a disease of unknown etiology which is a primary systemic vasculitis leading to stenotic and occlusive changes. Takayasu arteritis is a chronic inflammatory disease in progressive pattern which chiefly affects the aorta and its main branches. The diagnosis of the disease is mainly based on the clinical suspicion, history, physical examination and vascular imaging. We present here three cases of takayasu arteritis in pregnancy that were treated at our institute in the last 5 years. 1 st case had complications like severe preeclampsia, abruption, temporary loss of vision, and intra uterine death of fetus. In 2 nd case there was brain sparing effect of fetus, but other than that she did not have any other complications and neonatal outcome was also good without any neonatal complications. In the 3rd case antenatal and postnatal periods were uneventful and with good neonatal outcome. Pregnancy with takayasu arteritis needs to be timely diagnosed and treated for best maternal and fetal outcome.

Keywords: Takayasu arteritis, pregnancy, maternal and fetal outcome

\section{Introduction}

Takayasu arteritis is a disease of unknown etiology which is a primary systemic vasculitis leading to stenotic and occlusive changes.$^{1}$ In 1908 , a case was reported in a 21years old female with retinal arterio venous anastomosis by Japanese ophthalmologist Mikito Takayasu, hence this disease is named after him. ${ }^{2}$
Takayasu arteritis (TA) is also known as an occlusive thromboaortopathy, affecting women predominantly during their reproductive years (female to male ratio 4:1). The levels of sex steroid hormones like estrogen and progesterone were found to be higher in patients of TA whether in active or in stable stage, than those in healthy women, which points out that the elevated levels of sex steroids may be a key factor that can affect the pathogenesis of the disease. Its prevalence is variable with highest incidence in Asians especially Japanese and Orient. ${ }^{3}$

Etiology of the disease is not known but it may be due to infections or some other factors leading to immune damage. ${ }^{4}$ Studies have shown that the histocompatibility antigens have a prime role in the pathogenesis of Takayasu arteritis. ${ }^{5}$ Takayasu arteritis is a chronic inflammatory disease in progressive pattern which chiefly affects the aorta and its main branches leading to secondary hypertension, retinopathy, cardiac pathology, stroke and even premature death. 6 Infiltration of the adventitia of affected vessels by mononuclear cells is seen in early stages of the disease. ${ }^{7}$ Progression of the disease and inflammation leads to panarteritis resulting in fibrosis and stenosis of vessels.

Specific laboratory tests are not available for definitive diagnosis of the disease. ${ }^{8}$ The diagnosis of the disease is mainly based on the clinical suspicion, history, physical examination and vascular imaging. Diagnostic criteria for Takayasu arteritis was given by The American College Of Rheumatology as shown in table-1.

\begin{tabular}{|l|l|}
\hline \multicolumn{2}{|l|}{ Diagnostic criteria for Takayasu arteritis } \\
\hline 1 & Age at disease onset $<40$ years \\
\hline 2 & Claudication of extremities \\
\hline 3 & Decreased brachial artery pulses \\
\hline 4 & Systolic blood pressure difference $>10 \mathrm{~mm} \mathrm{Hg}$ \\
\hline 5 & Bruit over subclavian arteries or aorta \\
\hline 6 & $\begin{array}{l}\text { Arteriographic evidence of narrowing or occlusion of aorta, its primary branches or large arteries } \\
\text { in the proximal upper or lower extremities }\end{array}$ \\
\hline
\end{tabular}


Diagnosis of takayasu arteritis requires presence of any 3 out of the 6 criteria.

We present here three cases of takayasu arteritis in pregnancy that were treated at our institute in the last 5 years.

\section{CASE 1}

A 30ys, $\mathrm{G}^{3} \mathrm{P}^{2} \mathrm{~L}^{0}$ at 2 months gestation was admitted with severe hypertension in our hospital. She had complications in previous 2 pregnancies. In 1st pregnancy, at 7th month of gestational age she had sudden loss of vision associated with severe headache. Her blood pressure recording at that time was 90/ $60 \mathrm{~mm}$ of $\mathrm{Hg}$ in right arm and 200/160 mm of $\mathrm{Hg}$ in left arm. Subsequently, she complained of bleeding per vagina and decreased fetal perceptions .Following spontaneous onset of labour she delivered a dead male fetus. She gradually improved and vision also restored completely over 5 to 6 months. But due to financial strain, no further work up was done by the patient at that time.

In 2 nd pregnancy, at 7th month of gestational age she developed sudden weakening of both right upper and lower limbs. Upper limbs pulse and BP were not recordable. Blood pressure was 160/120 mm of $\mathrm{Hg}$ and 190/170 mm of $\mathrm{Hg}$ in right and left lower limbs respectively. Subsequently she started with bleeding per vagina and decreased fetal perceptions. Abruption with IUFD was diagnosed and so pregnancy was terminated by induction of labour with misoprostol. Post delivery $\mathrm{MRI}$ brain revealed massive pontine infarct and periventricular infarct. Angiogram was done in which aneurysmal dilatation and coarctation of aorta was noted. Carotid and vertebral Doppler revealed intimal thickening and stenosis of left CCA and ICA. Her clinical diagnosis was made as Takayasu Arteritis. Immediate postpartum she had complaints of orthopnea, for which she was managed conservatively. She was started on tablet Amlodipin 5mg, Atenolol 50mg, Ecospirin 325mg and Prednisolone $2 \mathrm{mg}$.

In present pregnancy she had her 1 st antenatal check up at 8 weeks of gestation. During general examination, her upper limb pulse and blood pressure were not recordable. Lower limb blood pressure was recorded to be $190 / 130 \mathrm{~mm}$ of $\mathrm{Hg}$. Obstetric ultrasound revealed blighted ovum. All routine blood investigations were normal. PT, APTT and INR were within normal range. CRP and ESR were slightly increased $(3 \mathrm{mg} / \mathrm{dl}$ and $35 \mathrm{~mm} / 1$ st hour respectively). Pregnancy was terminated by medical method. Post abortion she was stable and discharged on 4th post abortal day with advice for use of barrier contraceptives for contraception.

CASE 2

A 23 years old primigravida at 38 weeks of gestation and known case of takayasu arteritis was referred to our institute for safe institutional delivery. She was diagnosed to have takayasu arteritis at 5th month of this pregnancy .At that time she had difference in blood pressure recording of both upper limbs, right arm being 160/90 mm of Hg and left arm 120/100 mm of $\mathrm{Hg}$.MRI of aorta and neck revealed narrowing of lumen of left subclavian artery with wall thickening just distal to aneurysm of left vertebral artery suggestive of type 1 takayasu arteritis. She was started on tablet Labetelol 600mg in divided doses, Prednisolone $2 \mathrm{mg}$ and Amlodipin 10mg twice daily. On admission her blood pressure readings were right arm 180/ $110 \mathrm{~mm}$ of $\mathrm{Hg}$, left arm $150 / 90 \mathrm{~mm}$ of $\mathrm{Hg}$, right leg 170/100 $\mathrm{mm}$ of $\mathrm{Hg}$ and left leg $160 / 100 \mathrm{~mm}$ of $\mathrm{Hg}$. Her routine investigations were normal and Doppler study of fetus showed mild brain sparing changes. She was posted electively for LSCS under epidural anesthesia and delivered a single live male neonate of birth weight $2.8 \mathrm{~kg}$ with good Apgar score. Post operatively she was continued on tablet labetalol $200 \mathrm{mg}$ thrice a day and tablet Nicardia retard $10 \mathrm{mg}$ twice a day .Patient was discharged on post op day 6 in stable condition on hypertensive drugs.

\section{CASE 3}

A case of 22 years old primigravida at 37 weeks of gestation with known case of Takayasu arteritis was referred to our institute. She was diagnosed as Takayasu arteritis at 6th month of pregnancy. During her regular antenatal checkups there was a disparity of blood pressure in between upper limbs, right arm 180/100 mm of $\mathrm{Hg}$, left arm 110/70 mm of $\mathrm{Hg}$ and pulse in right upper limb was absent She was investigated for the same. MRI of aorta and upper limbs were done and revealed the intimal thickening of right subclavian artery. She was diagnosed as Type 1 Takayasu arteritis .Patient was posted for elective LSCS under epidural anesthesia in view of cephalo pelvic disproportion and moderate oligohydramnios (AFI 4-5). Patient delivered a single live male neonate of birth weight $3.2 \mathrm{~kg}$ with good Apgar score. Post operatively her blood pressure recordings in right arm was $170 / 90 \mathrm{~mm}$ of $\mathrm{Hg}$ and left arm was $110 / 70 \mathrm{~mm}$ of $\mathrm{Hg}$. Post partum period was uneventful and she was discharged on post op day 7 with stable vitals. 


\section{TABLE 2 : DETAILS OF THE CASES}

\begin{tabular}{|c|c|c|c|c|c|c|c|c|c|c|}
\hline $\begin{array}{l}\text { SL } \\
\text { No }\end{array}$ & Age & $\begin{array}{l}\text { Obst } \\
\text { Index }\end{array}$ & $\begin{array}{c}\text { Blood } \\
\text { Pressure } \\
\text { (in } \mathrm{mm} \text { of } \mathrm{Hg})\end{array}$ & $\begin{array}{l}\text { Time of } \\
\text { Diagnosis }\end{array}$ & $\begin{array}{c}\text { Prior } \\
\text { Treatment }\end{array}$ & $\begin{array}{l}\text { Compli- } \\
\text { cations }\end{array}$ & $\begin{array}{c}\text { Method of } \\
\text { Termination }\end{array}$ & $\begin{array}{c}\text { Method of } \\
\text { Anaesthesia }\end{array}$ & $\begin{array}{l}\text { Maternal } \\
\text { outcome }\end{array}$ & $\begin{array}{c}\text { Fetal } \\
\text { outcome }\end{array}$ \\
\hline Case & 30 & G3P2L0 & $\begin{array}{c}\text { Upper limbs - } \\
\text { not record- } \\
\text { able } \\
\text { RUL-160/120 } \\
\text { LUL-190/170 }\end{array}$ & \begin{tabular}{|c|} 
During \\
previous \\
pregnancy \\
2nd \\
trimester
\end{tabular} & $\begin{array}{c}\text { 1.Tablet } \\
\text { Amlodipin } \\
5 \mathrm{mg} \\
\text { OD2.Atenolol } \\
\text { 50mg OD } \\
\text { 3.Ecospirin } \\
\text { 325mg in } \\
\text { div doses } \\
\text { 4.Predniso- } \\
\text { lone } 2 \mathrm{mg} \\
\text { OD }\end{array}$ & \begin{tabular}{|} 
1. Abruption \\
2. IUFD \\
3. Hyperten- \\
sive retin- \\
opathy \\
4. Hyperten- \\
sion
\end{tabular} & $\begin{array}{c}\text { Medical } \\
\text { termination } \\
\text { of pregnancy } \\
\text { at } 8 \text { weeks of } \\
\text { gestation }\end{array}$ & ---- & \begin{tabular}{|c|} 
Had \\
weakness of \\
limbs in \\
previous \\
pregnan- \\
cies. In this \\
pregnancy, \\
she had \\
severe \\
hyperten- \\
sion ,stable \\
after \\
termination \\
of preg- \\
nancy
\end{tabular} & Abortion \\
\hline $\begin{array}{c}\text { Case } \\
2\end{array}$ & 23 & $\begin{array}{l}\text { Primi- } \\
\text { gravida }\end{array}$ & $\begin{array}{c}\text { RUL-180/110 } \\
\text { LUL-150/90 } \\
\text { RLL-170/100 } \\
\text { LLL-160/100 }\end{array}$ & $\begin{array}{l}\text { 2nd } \\
\text { trimester in } \\
\text { this } \\
\text { pregnancy }\end{array}$ & $\begin{array}{c}\text { 1.Tablet } \\
\text { Labetelol } \\
\text { 200mgTID } \\
\text { 2. Tablet } \\
\text { Amlodipin } \\
\text { 10mg BD } \\
\text { 3.Predniso- } \\
\text { lone } 2 \mathrm{mg} \\
\text { OD }\end{array}$ & $\begin{array}{c}\begin{array}{c}\text { 1.Brain } \\
\text { sparing } \\
\text { changes of } \\
\text { neonate } \\
\text { 2. Hyperten- } \\
\text { sion }\end{array} \\
\end{array}$ & $\mid \begin{array}{l}\text { Elective LSCS } \\
\text { at } 38 \text { weeks }\end{array}$ & $\begin{array}{c}\text { Continuous } \\
\text { epidural }\end{array}$ & $\begin{array}{l}\text { Continued } \\
\text { on antihy- } \\
\text { pertensive }\end{array}$ & $\begin{array}{c}\text { Term, male, } \\
\text { good APGAR } \\
\text { Birth Weight } \\
2.8 \mathrm{~kg}\end{array}$ \\
\hline $\begin{array}{c}\text { Case } \\
3\end{array}$ & 22 & $\begin{array}{l}\text { Primi- } \\
\text { gravida }\end{array}$ & $\begin{array}{c}\text { RUL-180/110 } \\
\text { LUL-150/90 } \\
\text { RLL-170/100 } \\
\text { LLL-160/100 }\end{array}$ & \begin{tabular}{|} 
2nd \\
trimester in \\
this \\
pregnancy
\end{tabular} & $\begin{array}{l}\text { Not on any } \\
\text { treatment }\end{array}$ & $\begin{array}{l}\text { Hyperten- } \\
\text { sion }\end{array}$ & $\begin{array}{l}\text { Elective LSCS } \\
\text { at } 37 \text { weeks }\end{array}$ & $\begin{array}{c}\text { Continuous } \\
\text { epidural }\end{array}$ & $\begin{array}{l}\text { Stable, no } \\
\text { medications } \\
\text { at the time } \\
\text { of discharge }\end{array}$ & $\begin{array}{c}\text { Term, male, } \\
\text { good APGAR } \\
\text { Birth Weight } \\
3.2 \mathrm{~kg}\end{array}$ \\
\hline
\end{tabular}

\section{IUFD- Intra uterine fetal demise}

LSCS-Lower segment caesarean section

\section{Discussion:}

Clinical classification of Takayasu arteritis has been given according to the site of the lesion. ${ }^{9}$ According to it cases can be divided into 4 types:

\section{TYPE 1 : CEPHALO -BRACHIAL TYPE (AORTIC ARCH} SYNDROME)

The carotid and vertebral arteries experience stenosis and occlusion, which can cause varying degree of cerebral ischemia, as seen in our 1st case, further BP in unilateral or bilateral upper limbs is reduced or cannot be detected.
2. TYPE 2 : THORACIC-ABDOMINAL TYPE

The lesion is located in descending aorta and abdominal aorta, causing lower limb weakness, intermittent claudication, hypertension, aortic valve insufficiency or even heart failure.

3. TYPE 3 : GENERALIZED TYPE

The patient has a combination of both types mentioned above or involving multiple lesions; most of the patients have severe lesions, which were fortunately absent in our cases.

\section{TYPE 4 : PULMONARY ARTERY TYPE}

The lesions are combined and located in the pulmonary artery which may lead to pulmonary hypertension. $25 \%$ of patients with pulmonary artery type have pulmonary hypertension. 10 
Takayasu arteritis (TA) is a chronic inflammatory vascular disease of unknown etiology. It usually affects aortic arch and its main branches, as seen in all 3 of our cases, but can also affect other segments of the aorta and pulmonary and renal arteries. ${ }^{11}$ TA is mainly characterized by leukocyte infiltration of intima and proliferation of myofibroblasts that invariably leads to vascular stenosis. Sometimes aneurysm formation may occur due to release of metaloproteases. Clinical features will depend on the artery that is affected. Subclavian and iliac artery involvement causes limb claudication. Carotid artery involvement leads to vertigo, renal arterial involvement leads to arterial hypertension, and some patient can progress to aortic insufficiency and congestive heart failure. ${ }^{12}$ Glucocorticoids are the first line of drugs for Takayasu arteritis in pregnancy as the inflammatory reaction in TA responds to it. If Prednisolone treatment fails, Azathoprine should be considered for the treatment. But clinical presentation is usually insidious \& diagnosis is often delayed, hence treatment is usually delayed as seen in all our 3 cases.

Pregnancy has no effect on the progression of the disease, but its incidence is peak in the 2 nd and $3 r d$ trimester. It needs special attention during this period in view of development of complications like abortions, preeclampsia and abruption ${ }^{13,14,15}$ Stenosis can lead to decreased blood flow, restricted intra uterine fetal growth, low birth weight babies and even fetal death. ${ }^{16,17,18}$ When bilateral renal involvement is present, the incidence of intrauterine growth restriction is very high. ${ }^{19}$ Gatto et al reported fetal growth restriction in $51.7 \%$ of fetuses in a study in India. ${ }^{13}$ Four most important complications of Takayasu arteritis are Takayasu's retinopathy as seen in our 1stcase, secondary hypertension which is most common (seen in all of our 3 cases), aortic regurgitation and aneurysm formation. Secondary hypertension is due to loss of elasticity and narrowing of arteries, along with abnormalities in functioning of aortic and carotid baroreceptors function. ${ }^{20} \mathrm{Blood}$ pressure should be strictly controlled in pregnancy as severe renovascular hypertension can lead to cardiac involvement, pulmonary hypertension and poor fetomaternal prognosis. ${ }^{21}$ Poor outcome like abortion, preterm labour and low birth babies can occur.

TA is usually diagnosed as a diagnosis of exclusion and presents late in pregnancy. Patients conceive without prior knowledge of having the disease and so they are not on any specific treatment for it. ${ }^{21}$

\section{CONCLUSION:}

Out of our 3 cases

1 1st case had complications like severe preeclampsia, abruption, temporary loss of vision, and intra uterine death of fetus.
2 In 2nd case there was brain sparing effect of fetus, but other than that she did not have any other complications and neonatal outcome was also good without any neonatal complications.

3 In the 3rd case antenatal and postnatal periods were uneventful and with good neonatal outcome.

Takayasu arteritis is a disease of unknown etiology affecting mainly the major vessels. Its presence in pregnancy can have variable outcomes as seen in our 3 cases. Some pregnancies may be very minimally affected, where as some others may have disastrous outcome. Pregnancy with takayasu arteritis needs to be timely diagnosed and treated for best maternal and fetal outcome. An interdisciplinary approach of obstetricians, cardiologists, rheumatologists, and neurologists is often necessitated for an optimal maternal and fetal outcome.

\section{REFERENCES}

1. Ishikawa K. Natural history and classification of occlusive thromboaortopathy (Takayasu's disease). Circulation. 1978;57(1):27-35. doi:10.1161/01.cir.57.1.27

2. Singh N, Tyagi S, Tripathi R, Mala YM. Maternal and fetal outcomes in pregnant women with Takayasuaortoarteritis: Does optimally timed intervention in women with renal artery involvement improve pregnancy outcome?. Taiwan J Obstet Gynecol. 2015; 54(5):597-602. doi:10.1016/j.tjog.2015.08.014

3. Matsumura A, Moriwaki R, Numano F. Pregnancy in Takayasu arteritis from the view of internal medicine. Heart Vessels Suppl. 1992; 7:120-124. doi:10.1007/ BF01744557

4. Lucena AJ, Carvalho AC, Souza JA, Moron AF, Sun SY, Born D. Pregnancy follow-up and outcome in a patient with Takayasu's arteritis. Arq Bras Cardiol. 2008;90(5):e33-e35. doi:10.1590/s0066-782×2008000500013

5. Johnston SL, Lock RJ, Gompels MM. Takayasu arteritis: a review. J ClinPathol. 2002;55(7):481-486. doi:10.1136/ jcp.55.7.481

6. Nalini S, Santa SA. Takayasu Arteritis with Bilateral Renal Artery Stenosis and Left Subclavian Artery Stenosis in Pregnancy. J ClinDiagn Res. 2015;9(9):QD07-QD8. doi:10.7860/JCDR/2015/14371.6485

7. Braunwald E, Zipes D, Libby P. Heart disease: a textbook of cardiovascular medicine, 6th ed. Philadelphia: WB Saunders; 2001.

8. Lupi-Herrera E, Sánchez-Torres G, Marcushamer J, Mispireta J, Horwitz S, Vela JE. Takayasu's arteritis. Clinical 
study of 107 cases. Am Heart J. 1977;93(1):94-103. doi:10.1016/s0002-8703(77)80178-6

9. Arend WP, Michel BA, Bloch DA, et al. The American College of Rheumatology 1990 criteria for the classification of Takayasu arteritis. Arthritis Rheum. 1990;33(8):1129-1134. doi:10.1002/art.1780330811

10. Hall S, Buchbinder R. Takayasu's arteritis. Rheum Dis Clin North Am. 1990;16(2):411-422.

11. Hunder GG. Classification and approach to the vasculitis in adults. Disponivelem: http://www.uptodate. comacessoem 2006 maio 13

12. de Jesús GR, d'Oliveira IC, dos Santos FC, et al. Pregnancy may aggravate arterial hypertension in women with Takayasu arteritis. Isr Med Assoc J. 2012;14(12):724-728.

13. Gatto M, laccarino L, Canova M, et al. Pregnancy and vasculitis: a systematic review of the literature. Autoimmun Rev. 2012;11(6-7):A447-A459. doi:10.1016/ j.autrev.2011.11.019

14. Ishikawa K. Natural history and classification of occlusive thromboaortopathy (Takayasu's disease). Circulation. 1978; 57(1):27-35. doi:10.1161/01.cir.57.1.27

15. F. G. Cunningham and W. J. Whitridge, Williams Obstetrics, McGraw-Hill Medical, New York, NY,USA, 23rd edition,2009.

16. Beilin Y, Bernstein H. Successful epidural anaesthesia for a patient with Takayasu's arteritis presenting for caesarean section. Can J Anaesth. 1993;40(1):64-66. doi:10.1007/ BF03009321

17. Kathirvel S, Chavan S, Arya VK, et al. Anesthetic management of patients with Takayasu's arteritis: a case series and review. AnesthAnalg. 2001;93(1):60-65. doi:10.1097/00000539-200107000-00014

18. Suri V, Aggarwal N, Keepanasseril A, Chopra S, Vijayvergiya $R$, Jain S. Pregnancy and Takayasu arteritis: a single centre experience from North India. J ObstetGynaecol Res. 2010;36(3):519-524. doi:10.1111/j.14470756.2010.01226.x

19. Ishikawa K, Maetani S. Long-term outcome for 120 Japanese patients with Takayasu's disease. Clinical and statistical analyses of related prognostic factors. Circulation. 1994; 90(4):1855-1860. doi:10.1161/ 01.cir.90.4.1855

20. Hauenstein E, Frank H, Bauer JS, Schneider KT, Fischer T. Takayasu's arteritis in pregnancy: review of literature and discussion. J Perinat Med. 2010;38(1):55-62. doi:10.1515/ jpm.2009.120

21. Assad AP, da Silva TF, Bonfa E, Pereira RM. Maternal and Neonatal Outcomes in 89 Patients with Takayasu Arteritis (TA): Comparison Before and After the TA Diagnosis. J Rheumatol. 2015;42(10):1861-1864. doi:10.3899/ jrheum. 150030

How to cite this article: Mohapatra I, Samantaray SR, Priyanka G, Achanta V . Takayasu arteritis in pregnancy: A case series. Perspectives in Medical Research 2020; 8 (2):109113. DOI : $10.47799 /$ pimr.0802.23

Sources of Support: Nil, Conflict of interest: None declared 